\title{
NIETZSCHE Y LA VALORACIÓN REACTIVA DE LO TEMPORAL: LAS PARADOJAS AXIOLÓGICAS DEL ETERNO RETORNO.
}

Nietzsche and the reactive valuation of the temporal: the axiological paradoxes of eternal recurrence of the same

\author{
Jaime Llorente
}

IES «Campo de Calatrava», Ciudad Real

RESUMEN: El pensamiento del eterno retorno de lo mismo constituye la más elevada expresión de las intuiciones de Nietzsche en referencia a la estructura del tiempo y la Historia. En el presente estudio se trata, en primer lugar, de proponer una interpretación acerca de las raíces ontológicas subyacentes a la concepción nietzscheana de la temporalidad (raíces localizadas en la propia estructura de la voluntad de poder). Tal interpretación permitiría mostrar posteriormente el modo en el que resulta posible considerar, desde un punto de vista axiológico, la «doctrina del retorno» como síntoma de una oculta valoración reactiva del devenir temporal.

Palabras clave: devenir - voluntad de poder - quanta - temporalidad

ABSTRACT: The thought of eternal recurrence of the same constitutes the highest expression of Nietzsche's intuitions in reference to the structure of time and history. In the present study we try to suggest, in the first place, an interpretation of the underlying ontological roots to Nietzsche's conception of temporality (roots to be found in the structure itself of will to power). Such interpretation would then allow us to show the way in which it is possible, from an axiological point of view, to consider «the doctrine of recurrence» as a symptom of a hidden reactive valuation of temporal becoming.

Keywords: Becoming - Will to Power - Quanta - Temporality

\section{INTRODUCCIÓN: LA TEORÍA HISTÓRICO-TEMPORAL NIETZSCHEANA ENTRE EL HORIZONTE Y LA INDETERMINACIÓN}

En su lección inaugural de 1789 en la Universidad de Jena, publicada posteriormente bajo el título «Was heisst und zu welchem Ende studiert man Universalgeschichte?»,(«Qué significa y cuál es la finalidad del estudio de la Historia Universal» Schiller, tras referirse al «instinto (Trieb) que impele irresistiblemente al espíritu filosófico a asimilar todo lo circundante a su propia naturaleza racional, y a elevar al pensamiento (zum Gedanken zu erheben) todo fenómeno que se le presente como el supremo efecto por él reconocido", describe la aplicación de tal instinto a la consideración de la temporalidad histórica en los siguientes términos:

Comienza, fenómeno tras fenómeno, a esquivar el ciego azar (blinden Ohngefähr), la libertad sin leyes, y a aproximarse a un Todo armónico (que solo existe, naturalmente, en su representación) como elemento apropiado. Enseguida le resulta difícil 